\title{
Phytoprotection
}

\section{Centre SÈVE}

\section{Christine Thériault, Anne-Marie Simao-Beaunoir et Carole Beaulieu}

Volume 85, numéro 2, août 2004

URI : https://id.erudit.org/iderudit/009832ar

DOI : https://doi.org/10.7202/009832ar

Aller au sommaire du numéro

Éditeur(s)

Société de protection des plantes du Québec (SPPQ)

ISSN

0031-9511 (imprimé)

1710-1603 (numérique)

Découvrir la revue

Citer cet article

Thériault, C., Simao-Beaunoir, A.-M. \& Beaulieu, C. (2004). Centre SÈVE.

Phytoprotection, 85(2), 73-79. https://doi.org/10.7202/009832ar d'utilisation que vous pouvez consulter en ligne.

https://apropos.erudit.org/fr/usagers/politique-dutilisation/ 


\title{
Centre SÈVE
}

\author{
Christine Thériault, Anne-Marie Simao-Beaunoir et Carole Beaulieu ${ }^{1}$
}

PHYTOPROTECTION $85:$ 73-79

\section{Centre SÈVE : sa mission}

La création du Centre SĖVE, en avril 2004, est au cœur même d'une volonté d'améliorer la productivité végétale du secteur agricole et de faire ainsi reconnaître l'expertise québécoise en matière d'agroenvironnement au niveau national et international. Le Centre SĖVE est un centre de recherche interinstitutionnel dont la mission consiste à développer des connaissances et des outils pour accroître la productivité végétale au Québec, et ce, en tenant compte de divers impératifs environnementaux et sociaux associés aux activités de recherche et de développement du secteur agronomique.

Au Québec, l'industrie bioalimentaire représente un secteur économique important et ses objectifs de développement dépendent d'un effort soutenu en recherche. Or, la croissance du secteur agroenvironnemental passe dorénavant par une conciliation entre les objectifs économiques et environnementaux. À cela s'ajoutent les cadres législatifs de plusieurs pays qui formulent désormais des attentes tangibles en ce qui concerne l'innocuité des aliments et la protection de l'environnement.

\section{Centre SÈVE : protection des végétaux et de l'environnement}

Concrètement, le programme de recherche du Centre SĖVE s'articule autour de deux thématiques, à savoir la protection des cultures dans un contexte législatif limitant I'utilisation de pesticides chimiques, et l'amélioration végétale dans une optique de réduction des émanations de gaz à effet de serre (GES) d'origine agricole. De plus, les impacts sociaux et environnementaux des travaux menés dans le cadre du Centre SÈVE sont évalués par des collaborateurs en éthique et en sciences environnementales (Figs. 1 et 2).

\section{Centre SÈVE's mission}

The creation of the Centre SÈVE in April 2004 arose from a strong will for the enhancement of plant productivity in the agricultural sector and the recognition of Quebec's expertise in agro-environmental issues at both the national and international levels. Centre SĖVE is an inter-institutional research centre focused on the development of knowledge and tools to enhance Quebec's plant productivity while maintaining environmental and social values in relation to research and development in the agronomic sector.

In Quebec, the bio-food industry is an important economic sector and its development depends on a sustained research effort. In the current context, the growth of the agro-environmental sector depends on maintaining a balance between economical and environmental considerations. These research efforts must also meet the legal expectations in regards to food safety and environmental protection.

Centre SÈVE : an environment friendly center The Centre SĖVE research programs are based on two main goals. The first is to improve plant protection so that chemical pesticide use can be reduced and the second is to enhance plant genetics to reduce agricultural green house gas (GHG) emissions. The social and environmental impacts of the this research will be studied by the Centre's specialists in ethics and in environmental sciences (Figs. 1 and 2)

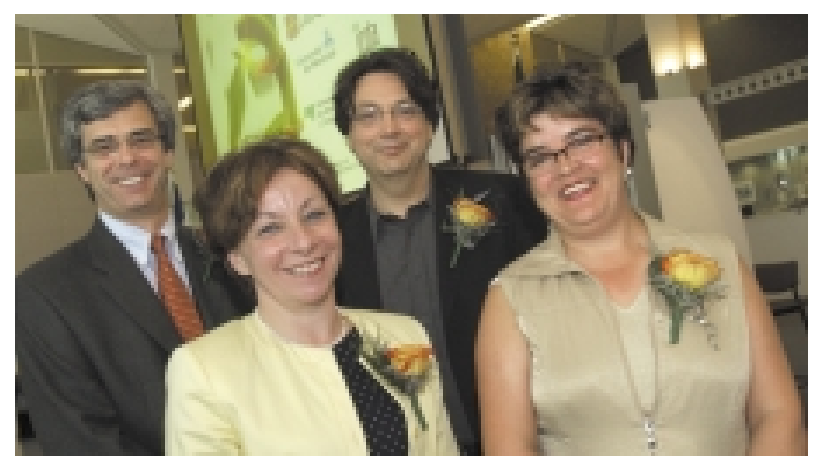

Figure 1. Comité de direction du Centre Sève : de gauche à droite, Marc Fortin, Louise Brisson, Alain Létourneau et Carole Beaulieu. Don Smith et Jacques Brodeur n'apparaissent pas sur la photo.
Figure 1. Centre SÈVE's management board : from left to right Marc Fortin, Louise Brisson, Alain Létourneau and Carole Beaulieu. Don Smith and Jacques Brodeur are not present.

1. Centre Sève, Département de biologie, Université de Sherbrooke, Sherbrooke (Québec), Canada J1K 2R1; www.centreseve.org 


\section{Coordination (Carole Beaulieu)}

\section{Recherche fondamentale et appliquée \\ I : Protection des plantes (Coordonnateurs : Louise Brisson et Jacques Brodeur) \\ A) Aspects fondamentaux de phytoprotection \\ B) Régie biologique des cultures}

II : Amélioration végétale (Coordonnateurs : Marc Fortin et Don Smith)

A) Potentiel génétique

B) Végétaux et GES

C) Développement de bioproduits

Thème intégrateur : Interaction-plante

Résultats attendus

- Accroissement de la productivité végétale

- Réduction des émissions de GES

- Réduction de I'utilisation des intrants chimiques

Interfaces sociales et environnementales

(Coordonnateur : Alain Létourneau)

Évaluation des impacts sociaux et environnementaux

Résultats attendus

Contribution au débat social :

- Outils d'aide à la décision

- Évaluation du risque

- Outils d'éducation publique

Figure 2. Programmation scientifique du Centre SÈVE.

\section{Coordinator (Carole Beaulieu)}

Basic and applied research

I : Plant protection

(Coordinators: Louise Brisson and Jacques Brodeur)

A) Basic aspects of plant protection

B) Biological crop management
II : Plant genetics enhancement (Coordinators: Marc Fortin and Don Smith)

A) Genetic potential

B) Plants and GHG

C) Bio-products development
Social and environmental interface

(Coordinator: Alain Létourneau)

Evaluation of environment and social impacts

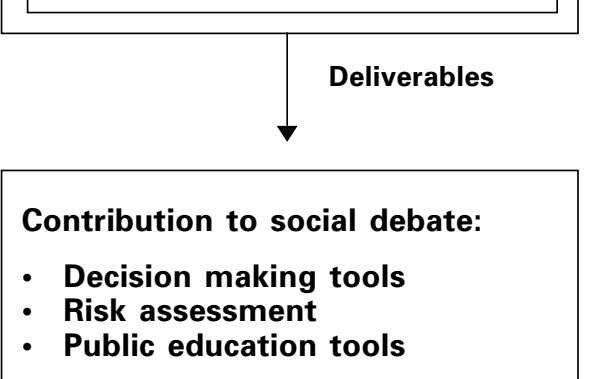

Figure 2. Centre SÈVE's scientific program. 
Le premier volet de la thématique portant sur la protection des cultures comprend l'étude des mécanismes impliqués dans la résistance et la tolérance des plantes aux agents pathogènes, et dans la virulence des organismes pathogènes. Les objectifs de ce premier volet visent :

- I'identification des bases moléculaires et physiologiques impliquées dans les interactions entre la plante et son environnement telle la caractérisation des rôles de facteurs de transcription impliqués dans la réaction de défense;

- I'identification des facteurs de pouvoir pathogène de certains microorganismes;

- I'identification des gènes et des protéines impliqués dans les mécanismes de résistance;

- l'étude de l'interaction d'agents phytopathogènes avec du matériel végétal résistant ou sensible.

Les objectifs de recherche du deuxième volet de la thématique sur la protection des cultures visent l'élaboration de stratégies d'action permettant une utilisation rationnelle des intrants chimiques. Les travaux de recherche compris dans ce volet portent sur une approche holistique en phytoprotection. Ils incluent l'étude de microorganismes utiles dans la lutte biologique, l'évaluation de l'impact de divers stress biotiques ou abiotiques sur des ravageurs des cultures et l'utilisation d'éliciteurs, seuls ou combinés à d'autres molécules végétales. Des recherches sur de nouvelles méthodes de culture, comme l'utilisation de biofertilisants et de molécules bénéfiques pour la croissance des plantes, sont aussi intégrées à ce deuxième volet. L'intégration de ces travaux devrait permettre de déterminer les conditions optimales menant à un niveau élevé de protection des cultures.

Les objectifs généraux de la thématique sur I'amélioration végétale visent la compréhension des paramètres physiologiques et génétiques qui contrôlent la productivité des plantes cultivées dans le but de réduire les GES émis par le Québec. La réduction des GES passe par des modifications profondes de la physiologie et de l'anatomie des plantes cultivées. Ces modifications devraient permettre d'augmenter les réserves de carbone présentes dans les racines et de maximiser les performances photosynthétiques des cultures. La réduction des GES englobe également la réduction des efflux de $\mathrm{N}_{2} \mathrm{O}$ en utilisant des microorganismes qui s'associent aux plantes. Les GES générés par des activités horticoles en milieu urbain sont aussi l'objet de travaux de recherche. L'ensemble de activités de recherche devrait avoir un impact favorable sur la durabilité des écosystèmes agricoles et des écosystèmes associés. Les intervenants dans cette thématique sont aussi impliqués dans le support de la chaîne de l'innovation qui mènera à de nouveaux produits dont il deviendra possible d'acquérir des droits sur la propriété intellectuelle.

Les activités de recherche des deux thématiques convergent vers des projets communs, comme l'étude de la virulence et de la non-virulence d'agents pathogènes dans des conditions où une augmentation des GES est probable dans un avenir rapproché. L'évaluation de l'impact de la rationalisation de l'usage
The fist objective of improving plant protection includes the study of the mechanisms involved in plant resistance and/or tolerance to plant pathogens and in altering the pathogen's virulence. This research will target the identification and characterization of:

- physiological and molecular mechanisms involved in plant-environment interactions such as the characterization of transcription factors and the role they have in plant defense reactions;

- pathogenicity factors utilized by micro-organisms;

- genes and proteins involved in resistance mechanisms;

- interactions between plant pathogens and resistant or susceptible plant material.

The second objective of improving plant protection targets the development of action strategies that would lead to the strategic use of chemical inputs. Included in these studies is the development of a holistic approach to plant protection. This includes the study of beneficial micro-organisms in biological control and the use of elicitor compounds or elicitor compounds in combination with other plant molecules. Research on new crop practices such as the use of bio-fertilizers and beneficial molecules for plant growth are also included in this second objective. The integration of these studies will lead to the identification of optimum conditions for achieving a high level of crop protection.

The goal of plant genetic enhancement focuses on understanding genetic and physiologic parameters controlling crop productivity and using this information to reduce the GHG emissions produced by crops in Quebec. The reduction of GHG emissions can only be achieved by substantial modifications in plant anatomy and physiology. These modifications would increase the carbon in root stocks and would maximize crop photosynthetic performance. The reduction of agricultural GHG would also target the reduction of $\mathrm{N}_{2} \mathrm{O}$ emissions through the use of plant associated micro-organisms. GHG emissions from agricultural activities in urban environments are also being investigated. These studies should improve the sustainability of agricultural and associated ecosystems. Scientists working in these areas of research are also involved in the maintenance of the innovation process that will lead to the development of new products for which intellectual property rights could be acquired.

Research efforts within these two main goals will overlap such as in the study of pathogen virulence or non-virulence under conditions where an enhancement of GHG emissions is possible. Evaluation of the impact of the strategic use of pesticides on agricultural GHG emissions is also under investigation. The possibility that crop practices aimed to reduce GHG emissions would affect plant sensitivity to some pathogens and would therefore cause an increase in the chemical pesticides needed in OGM crop practices will also be studied.

The scientific program at Centre SÈVE is a dynamic one and will adapt to new research findings. The Centre evaluates the impact of its research on user needs and social and legal factors. 
des pesticides sur les émanations de GES est aussi à l'étude. De même, la possibilité que des pratiques agricoles ayant pour but de réduire les GES puissent agir sur la sensibilité de certaines plantes à l'égard des agents pathogènes et donc nécessiter une utilisation accrue de pesticides de synthèse dans la régie de culture d'OGM végétaux est aussi abordée.

La programmation scientifique du Centre SÈVE est dynamique et est appelée à évoluer à la lumière des résultats des travaux de recherche, des réflexions sur les impacts de ces recherches, des besoins des utilisateurs, et du contexte législatif et social.

\section{Centre SÈVE : un centre de recherche unique en son genre}

Une des originalités de la recherche menée par les membres du Centre SĖVE réside dans la préoccupation de ces derniers de connaître les impacts environnementaux et sociaux des résultats de leurs travaux et de prendre en compte les préoccupations des utilisateurs de la recherche et des décideurs politiques, mais surtout du grand public face aux nouvelles technologies. L'interface environnementale et sociale a donc pour but d'aider les chercheurs en sciences biologiques à évaluer les impacts environnementaux et sociaux des résultats de leur recherche. Pour ce faire, il faut, d'une part, amener les chercheurs en biologie végétale à se prononcer sur des questions susceptibles de rencontrer l'intérêt social et, d'autre part, rendre possible des discussions publiques sur ces questions entre les biologistes et le public. La première étape de ce processus consiste à former des groupes de discussion composés de chercheurs et de collaborateurs de différentes universités affiliées au Centre SĖVE qui sont intéressés par les aspects éthiques, sociaux et environnementaux des sciences du vivant végétal. Des étudiants de deuxième et troisième cycles pourraient être intégrés dans ces groupes de discussion. Pour rendre compte publiquement des impacts environnementaux et sociaux de leurs travaux, les chercheurs impliqués dans les dossiers de productivité végétale feront d'abord le point sur les recherches qui sont présentement menées. Ils poursuivront aussi l'analyse de l'opinion publique et suivront les deux débats de société majeurs en biologie végétale, soit la production d'OGM et I'opposition entre l'approche "traditionnelle " et l'approche "biologique " en agriculture, tant sur le plan national qu'international, dans un contexte "industriel " de production agricole. Afin d'entrer dans une discussion publique, les chercheurs impliqués en productivité végétale, ainsi que ceux en sciences humaines devront développer des positions critiques sur les différents dossiers dans lesquels ils sont impliqués. La collaboration des chercheurs de sciences humaines et sociales est aussi mise à contribution lors de l'analyse des aspects politiques, légaux et économiques relatifs à la production végétale. Finalement, reste la question du risque : ce qui le caractérise, son évaluation, ainsi que sa "gestion ".

Les réponses aux questions éthiques et sociales soulevées par les sciences du vivant et particulièrement en biologie végétale passent par une éducation publique, qui devrait être aussi une éducation mutuelle, d'où la nécessité de développer des outils pédagogiques et des interventions publiques à caractère

\section{Centre SÈVE : one of a kind!}

Centre SĖVE is an original concept because its scientific members are concerned about both the environmental and the social impact of their research. They are sensitive not only to the needs of the users of the research, policy makers and the public but also to their concerns regarding the responsible use of biotechnology. The environmental and social interface will help researchers in biological science address these concerns. To do so, scientists in plant biology will have to take an open and public position on matters of social interest and be available for discussions regarding their research. The first step in this process consists of the formation of discussion groups where biological and social scientists from the universities affiliated with the Centre and concerned by ethics, social and environmental aspects of plant science, could exchange views on these issues. Graduate students would also be included in these discussion groups. Scientists must consider the environmental and social impacts of their research when evaluating ongoing studies. They should analyze public opinion and follow two important social debates in plant biology: GMO production and the opposition between conventional and biological agriculture in the context of large scale agricultural production on both domestic and international levels. And, to participate in public debates, scientists in plant biology and colleagues in ethics and the environment would have to develop critical opinions about the ongoing research projects that they are involved in. Researchers in ethics and the environment will also contribute in the analysis of the political, legal and economical aspect s of plant production. They will also have to consider the risks involved and be sure to characterize, evaluate and manage these risks appropriately.

Ethical and social concerns about biological sciences and, more specifically, about plant sciences can only be addressed through public education, which has to be a bilateral education. Methods to develop educational tools and public forums with educational purposes are also being developed. Communication with the public can be done by discussions in workshops and presentations, or forums in main university centers. Research results would also be available through the Centre SĖVE website (www.centreseve.org). 


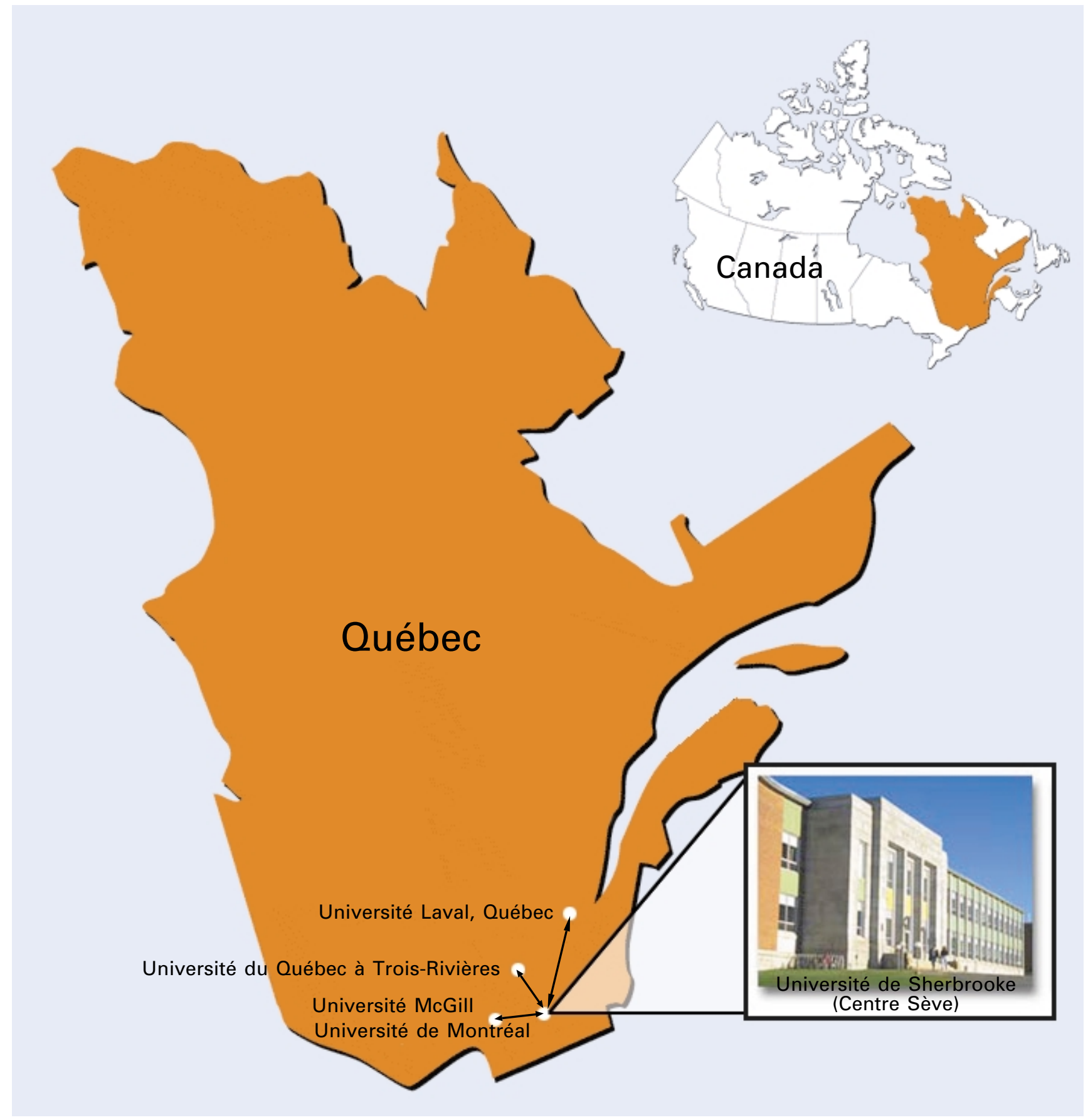

Figure 3. Institutions affiliées au Centre SÈVE (IRDA et Agriculture et Agroalimentaire Canada ne sont pas représentés). Le centre administratif du Centre est situé à l'Université de Sherbrooke.
Figure 3. Institutions affiliated to Centre SÈVE (IRDA and Agriculture and Agri-Food Canada not shown). Management center is located in Université de Sherbrooke. 
éducatif sur toutes les questions traitées. La communication avec le public pourra se faire par l'intermédiaire d'ateliers de discussion, de présentations ou de débats publics dans les principaux centres universitaires. Les résultats de recherche seront diffusés via le site Web du Centre SÈVE: www.centreseve.org.

\section{Centre SÈVE : un centre de liaison et de transfert technologique}

Le centre rassemble plus de 50 chercheurs provenant de milieux universitaires (Université de Sherbrooke, Université Laval, Université de Montréal, Université McGill, Université du Québec à Trois-Rivières) et gouvernementaux (Institut de recherche et de développement en agroenvironnement, et Agriculture et Agroalimentaire Canada) (Fig. 3). En regroupant ainsi les forces vives de la recherche en sciences végétales au Québec, le Centre SĖVE devient le seul centre de recherche au Québec composé de scientifiques en biologie végétale à vocation non forestière.

Le Centre SÈVE compte plus de 200 étudiants des cycles supérieurs et stagiaires postdoctoraux. II crée un milieu de formation de haute qualité qui offre un encadrement multidisciplinaire innovateur. Le Centre favorise les travaux de recherche où les co-directeurs sont rattachés à différentes unités de recherche, et ce, afin de multiplier les expériences de recherche des étudiants.

Le Centre SÈVE veut également assurer la liaison entre ses chercheurs et les utilisateurs de leurs recherches (les producteurs et les industriels), les instances gouvernementales et le grand public. La liaison entre les chercheurs du Centre SĖVE est assurée par des rencontres périodiques entre les intervenants des différentes thématiques et un bulletin d'information, Info-SËVE. Le bulletin sera publié en français et en anglais, et chacune des versions sera disponible sur le site Internet du Centre SĖVE.

Des rencontres sont aussi prévues entre les chercheurs, les industriels et les producteurs agricoles afin de favoriser la diffusion des résultats de recherche et leur transfert technologique éventuel. Pour ce faire, le Centre SĖVE a donc établi une entente avec le Centre québécois de valorisation des biotechnologies (COVB). Le COVB est un centre de liaison et de transfert (CLT) supporté par le ministère du Développement économique et régional et de la Recherche du Québec.

Le CQVB joue un rôle-clé en début de chaîne de valorisation. Il a pour mission de stimuler l'innovation dans les bio-industries québécoises et de soutenir les démarches de développement et de transfert de technologies issues de la recherche afin de générer de nouvelles richesses collectives. Parmi les activités de transfert technologique offertes par le Centre SĖVE et en collaboration avec le COVB, on retrouve :

- I'élaboration de stratégies de développement en R-D;

- des rencontres de prospection suscitant des échanges entre les membres et les partenaires, et permettant I'arrimage entre les services disponibles et les besoins des intervenants;
Centre SÈVE : a liaison and transfer center

Centre SĖVE gathers more than 50 scientists from universities (Université de Sherbrooke, Université Laval, Université de Montreal, McGill University and Université du Québec à Trois-Rivières) and governments (Institut de recherche et de développement en agroenvironnement, and Agriculture and Agri-Food Canada) (Fig. 3). In bringing together these vital forces in plant science, Centre SËVE becomes the first research centre in Quebec, of non forestry vocation, in plant biology.

The Centre SÈVE has more than 200 graduate and post-doctorial students. The center creates a high quality education environment offering an innovative cross-disciplinary training opportunity. Centre SËVE promotes the co-direction of students by supervisors belonging to different research units. This allows students to experiment in as many research contexts as possible.

The Centre SĖVE acts as a liaison center not only for its members, but also for its members and the users of their research (producers and industry representatives), policy makers and the public.

Regular meetings between scientists and their colleagues, and a newsletter (Info-SEVE) ensure the sharing of information between members of the center. This newsletter will be published in French and English, and both versions will be available on the Centre SĖVE website.

Meetings between scientists, industry representatives, and producers will promote information sharing and will eventually lead to technology transfer. Therefore, Centre SĖVE has made an agreement with Centre québécois de valorisation des biotechnologies (CQVB). CQVB is a liaison and transfer center (LTC) subsided by the ministère du Développement économique et régional et de la Recherche du Québec. CQVB plays a key role in the beginning of the development chain. Its mission is to stimulate innovation in Quebec's bio-industry and to support the development of procedures and technologies to generate new social wealth. Some of the technology transfer activities offered by Centre SEVE in collaboration with COVB include:

- development of research and development strategies;

- sponsoring meetings where members and partners can exchange and where connections between available services and collaborator needs can be made;

- helping to identify areas of research that industry partners and university members consider a priority.

Centre SÈVE strives to involve students in technology transfer activities and in science promotion.

Centre SÈVE will communicate with the public by maintaining an open door policy and through the Centre SĖVE website. 
- des rencontres technologiques sur des problématiques ciblées comme étant prioritaires tant par les partenaires industriels que les membres universitaires.

De plus, le Centre SÈVE désire associer ses étudiants à des activités de transfert technologique et de vulgarisation sous la forme d'ateliers.

Le grand public pourra aussi être rejoint grâce à diverses activités telles que les portes ouvertes et le site Internet du Centre.

Au Québec, pendant longtemps, une image passéiste a été associée à la recherche en agroalimentaire, plus particulièrement auprès du grand public. Le Centre SEVE, par la nature même de ses travaux de recherche liés à des préoccupations éthiques, sociales et environnementales, par la diversité des approches retenues et par le choix des technologies de pointe, devient une vitrine ouverte sur le Québec et sur le monde du savoir-faire québécois en biologie végétale. Le Centre SĖVE peut s'enorgueillir de compter parmi ses membres les meilleurs chercheurs en biologie végétale au Québec. Leur implication dans des activités de recherche et leur dynamisme font du Centre SĖVE un groupe de recherche unique en son genre. Dans l'avenir, le Centre vise à promouvoir davantage l'expertise québécoise en matière agroenvironnementale et à étendre ainsi ses collaborations au niveau national et international.

\section{Remerciements}

Les auteurs remercient les membres et les partenaires du Centre Sève pour leur collaboration aux activités scientifiques, et le Fonds québécois de recherche sur la nature et les technologies pour son financement.
In Quebec, agro-food research has been perceived as being outdated, especially by the public. Centre SĖVE, by the very special nature of its research programs, through the ethical, social and environmental impacts of its research, and by the wide array of approaches and leading technologies that it provides in the field of plant science, becomes a display for Quebec, and for the world, of Quebec's know-how in plant biology. Centre SĖVE is proud to have gathered the best scientists in plant biology in Quebec. Its members' enthusiasm and dedication make the Centre SÈVE a unique research group. In the future, Centre SĖVE will play an important role in promoting more and more of Quebec's expertise in agro-environment and extend the list of its contributors to national and international levels.

\section{Acknowledgements}

The authors wish to thank SÈVE's members and partners for their collaboration on scientific activities, and the Fonds québécois de recherche sur la nature et les technologies (FQRNT) for its financial support. 